\title{
Effect of source of trace minerals in either forage- or by-product-based diets fed to dairy cows: 2 . Apparent absorption and retention of minerals
}

\author{
M. J. Faulkner, ${ }^{1}$ N. R. St-Pierre, ${ }^{2}$ and W. P. Weiss ${ }^{3}$ \\ Department of Animal Sciences, Ohio Agricultural Research and Development Center, The Ohio State University, Wooster 44691
}

\begin{abstract}
Eighteen multiparous cows were used in a split-plot replicated Latin square with two 28 -d periods to evaluate the effects of source of supplemental $\mathrm{Cu}, \mathrm{Zn}$, and Mn (sulfates or hydroxy) on apparent absorption of minerals when fed in either a forage- or by-productbased diet. The by-product diets were formulated to have greater concentrations of NDF and lesser concentrations of starch, and specific ingredients were chosen because they were good sources of soluble fiber and $\beta$-glucans, which bind trace minerals in nonruminants. We hypothesized that hydroxy trace minerals would interact less with digesta and have greater apparent absorption compared with sulfate minerals, and the difference in apparent absorption would be greater for the by-product diet compared with the forage-based diet. During the 56-d experiment, cows remained on the same fiber treatment but source of supplemental trace mineral was different for each 28-d period; thus, all cows were exposed to both mineral treatments. During each period cows were fed no supplemental $\mathrm{Cu}, \mathrm{Zn}$, or $\mathrm{Mn}$ for $16 \mathrm{~d}$, followed by $12 \mathrm{~d}$ of feeding supplemental minerals from either sulfate or hydroxy sources. Supplemental minerals for each of the mineral sources fed provided approximately 10, 35, and $32 \mathrm{mg} / \mathrm{kg}$ of supplemental $\mathrm{Cu}, \mathrm{Zn}$, and $\mathrm{Mn}$, respectively, for both fiber treatments. Total $\mathrm{Cu}, \mathrm{Zn}$, and Mn dietary concentrations, respectively, were approximately 19, 65, and $70 \mathrm{mg} / \mathrm{kg}$ for the forage diets and 21,85 , and 79 for the by-product diets. Treatment had no effect on dry matter intake $(24.2 \mathrm{~kg} / \mathrm{d})$ or milk production $(34.9 \mathrm{~kg} / \mathrm{d})$. Cows consuming the by-product diets had greater $\mathrm{Zn}$ (1,863 vs. $1,453 \mathrm{mg} / \mathrm{d})$ and $\mathrm{Mn}(1,790$ vs. $1,588 \mathrm{mg} / \mathrm{d})$ intake compared with cows fed forage diets, but apparent $\mathrm{Zn}$ absorption was similar between treatments. Manganese apparent absorption was greater for the
\end{abstract}

Received October 3, 2016.

Accepted March 4, 2017.

${ }^{1}$ Current address: VitaPlus, Madison WI 53713.

${ }^{2}$ Current address: Perdue AgriBusiness, Salisbury, MD 21804.

${ }^{3}$ Corresponding author: weiss.6@osu.edu by-product diets compared with the forage diets (16 vs. $11 \%)$. A fiber by mineral interaction was observed for $\mathrm{Cu}$ apparent absorption, as cows fed hydroxy minerals with forage diets had greater apparent absorption compared with cows fed sulfate minerals; however, the opposite was observed with the by-product diets. Source of supplemental trace minerals and type of fiber in diets affected availability of $\mathrm{Cu}$ and $\mathrm{Mn}$ and should be considered in ration formulation.

Key words: mineral, fiber, by-product, digestibility

\section{INTRODUCTION}

As animal production intensifies and environmental constraints increase, chemical and physical forms of minerals and potential interactions of minerals with other feedstuffs must be considered during diet formulation. Substitution of forage fiber with nonforage fiber by-products in dairy rations has been successful (Clark and Armentano, 1993) and can be economically beneficial in certain situations. However, inclusion of small-particle by-products can decrease ruminal $\mathrm{pH}$ and the consistency of the rumen mat. These can decrease the rate and extent of fiber digestion and increase the rate of fiber passage (Grant, 1997). Increased flow of undigested fiber fractions increases the binding of divalent minerals, such as $\mathrm{Cu}$ and $\mathrm{Zn}$, within the gastrointestinal tract, reducing mineral availability in nonruminants (Drews et al., 1979; van der Aar et al., 1983); however, this has not been studied in ruminants. Binding of polyvalent metal ions to fiber is enhanced in low-pH environments (Torre et al., 1991), similar to that found in the abomasum and proximal small intestine. Increased flow of undigested fiber in by-product diets could increase cationic binding with minerals to a greater extent than observed with forge-based diets.

Decreasing the disassociation of metals in the rumen limits potential antagonism with other digesta, such as fiber fractions, and could increase bioavailability of trace minerals. Hydroxy $\mathrm{Cu}$ and $\mathrm{Mn}$ (IntelliBond; Micronutrients USA LLC, Indianapolis, IN) are less soluble in the rumen compared with sulfate sources (Genther and Hansen, 2015); however, data are not consistent regarding differences in Zn solubility between 
sulfate and hydroxy sources (Cao et al., 2000; Genther and Hansen, 2015). The decreased rumen solubility of hydroxy $\mathrm{Cu}$ and $\mathrm{Mn}$ make these a good experimental model for evaluating the potential antagonistic effects of fiber on apparent mineral absorption in ruminants. The primary objective of our study was to determine whether apparent $\mathrm{Cu}, \mathrm{Zn}$, and $\mathrm{Mn}$ apparent absorption and retention in lactating dairy cows are affected by the interaction between forage or by-product diets and trace minerals.

\section{MATERIALS AND METHODS}

\section{Cows and Treatments}

All animal procedures were approved by The Ohio State University Institutional Animal Care Committee. Prior to the experiment, all cows used in the experiment were fed diets that contained 15 to $20 \mathrm{mg} / \mathrm{kg}$ of total $\mathrm{Cu}, 50$ to $60 \mathrm{mg} / \mathrm{kg}$ of total $\mathrm{Zn}$, and 40 to $50 \mathrm{mg} /$ $\mathrm{kg}$ of total Mn for several months and should have had adequate body stores of those trace minerals.

Eighteen Holstein cows (7, 6, and 5 in second, third, and fourth lactation, respectively) were assigned to 3 groups of 6 cows based on DIM $(153 \pm 36$ DIM at the start of the experiment). Groups consisted of 6 cows because only 6 stalls designed for total collection of feces and urine are available at our research center. Therefore, within a group and period, treatment replications were not balanced (i.e., within each period, 2 treatments were fed to 2 cows each and 2 treatments were applied to only 1 cow each). However, over the entire experiment, replication was balanced. Within a group, 3 cows were randomly assigned to either a forage-based diet or a by-product-based diet, and remained on the diet throughout the 56-d experiment. Then, each cow was assigned to 1 of 2 mineral treatment sequences. Hence, the experimental design is a split-plot Latin square with two 28 -d periods. Each of the 28 -d periods consisted of a 16-d phase where no supplemental $\mathrm{Cu}$, $\mathrm{Zn}$, or Mn were fed, followed by a 12-d phase of feeding either sulfate or hydroxy (IntelliBond C, Z, and M; Micronutrients USA LLC) supplemental minerals. Diet ingredients and nutrient composition are in Tables 1,2 , and 3 . Forage and by-product diets were formulated to provide different concentrations of NDF and starch (Table 2). To achieve differing NDF and starch concentrations, a portion of corn silage, alfalfa silage, and all corn grain from the forage diet were replaced with rolled oats, dried corn gluten, dried beet pulp, and soy hulls in the by-product diet (Table 1). These ingredients (Table 2) were chosen to increase dietary concentrations of soluble fiber (specifically, $\beta$-glucans and pectin), which have negatively influenced min- eral absorption in nonruminants (Torre et al., 1991). Supplemental trace minerals were provided in a top dress (a mix of the appropriate concentrate plus appropriate amount of either sulfate or hydroxyl $\mathrm{Cu}, \mathrm{Mn}$, and $\mathrm{Zn}$ ) fed at $0.2 \mathrm{~kg} / \mathrm{d}$. This rate supplied dietary concentrations of 10,35 , and $30 \mathrm{mg} / \mathrm{kg}$ of diet DM of supplemental $\mathrm{Cu}, \mathrm{Zn}$, and $\mathrm{Mn}$ based on average DMI. Actual concentrations of supplemental minerals were similar and close to the target (Table 3). As expected, concentrations of trace minerals in basal diets differed because they were based on different ingredients. Additional information regarding materials and methods are reported in the companion paper (Faulkner and Weiss, 2017).

Cows were housed in individual tiestalls and fed once daily with a target refusal rate of $5 \%$ delivered feed. Cows were milked twice daily at approximately 0200 and $1400 \mathrm{~h}$ (milk yields were measured electronically). Individual feed delivery and refusal amounts were weighed and recorded daily.

\section{Digestion Collection and Feed Samples}

On d 24 of each period (d 8 of feeding supplemental minerals) cows were moved to specifically designed stalls and total output of milk, urine, and feces was measured for $4 \mathrm{~d}$ (Weiss et al., 2009). Urine and milk collection containers were acid-washed (50\% sulfuric acid) before each collection period, and fecal and feed samples were stored in new plastic bags. Urine (not acidified), milk, orts, and feeds were sampled daily (kept refrigerated) and composited (within cow) over the $4 \mathrm{~d}$. Water intake was measured and recorded daily during the collection periods by water meters connected to each individual water bowl. Silage, fecal, and refusal samples were frozen, lyophilized, and ground through a 1-mm screen (Wiley mill; Arthur H. Thomas Co., Philadelphia, PA). Concentrates were ground but not dried. Feed, orts, and fecal samples were sent to Cumberland Valley Analytical Services (Hagerstown, MD) for mineral analyses using standard wet chemistry methods (AOAC International, 2000; CVAS, 2014). Mineral samples were ashed $\left(1 \mathrm{~h}\right.$ at $\left.535^{\circ} \mathrm{C}\right)$, digested in $15 \%$ nitric acid, diluted, and assayed by inductively coupled plasma emission spectroscopy. Methods for feed analyses were described in a companion manuscript (Faulkner and Weiss, 2017).

On d 28, blood samples were collected from the tail vein into trace mineral free vacutainers (BD Vacutainer, Franklin Lakes, NJ) for serum and into heparinized tubes for whole blood assays. Whole blood was assayed in duplicate for hemoglobin (Kit Cat. No. MAK115, Sigma-Aldrich, St. Louis, MO) and superoxide dismutase (SOD) activity (Ransod SD 125, Randox Laboratories, Crumlin, UK). Blood was allowed to clot; 
FAULKNER ET AL.

Table 1. Ingredient composition of the $\operatorname{diet}^{1}(\%$ of DM)

\begin{tabular}{|c|c|c|c|c|}
\hline \multirow[b]{2}{*}{ Ingredient } & \multicolumn{2}{|c|}{ Forage } & \multicolumn{2}{|c|}{ By-product } \\
\hline & Sulfate & Hydroxy & Sulfate & Hydroxy \\
\hline Corn silage & 44.0 & 44.0 & 20.0 & 20.0 \\
\hline Alfalfa silage & 20.0 & 20.0 & 15.0 & 15.0 \\
\hline Ground corn & 18.5 & 18.5 & - & - \\
\hline Soybean meal, $48 \%$ CP & 14.9 & 14.9 & 8.5 & 8.5 \\
\hline Rolled oats & - & — & 14.1 & 14.6 \\
\hline Dried corn gluten feed & - & - & 11.0 & 11.0 \\
\hline Dried beet pulp & - & - & 15.0 & 15.0 \\
\hline Soy hulls & - & - & 14.1 & 14.1 \\
\hline Animal/vegetable fat & 0.51 & 0.51 & 0.65 & 0.65 \\
\hline Limestone & 0.69 & 0.69 & 0.47 & 0.47 \\
\hline Magnesium oxide & 0.16 & 0.16 & 0.07 & 0.07 \\
\hline Dicalcium phosphate & 0.25 & 0.25 & 0.13 & 0.13 \\
\hline Iodized salt & 0.48 & 0.48 & 0.42 & 0.42 \\
\hline Selenium premix ${ }^{2}$ & 0.15 & 0.15 & 0.15 & 0.15 \\
\hline Vitamin $\operatorname{mix}^{3}$ & 0.37 & 0.37 & 0.37 & 0.37 \\
\hline $\mathrm{Cu}$ sulfate & 0.0003 & - & 0.0003 & - \\
\hline Zn sulfate & 0.0008 & - & 0.0008 & - \\
\hline Mn sulfate & 0.0008 & - & 0.0008 & - \\
\hline Hydroxy $\mathrm{Cu}^{4}$ & - & 0.0001 & - & 0.0001 \\
\hline Hydroxy $\mathrm{Zn}^{4}$ & - & 0.0005 & - & 0.0005 \\
\hline Hydroxy $\mathrm{Mn}^{4}$ & - & 0.0006 & - & 0.0006 \\
\hline
\end{tabular}

${ }^{1}$ Forage- or by-product-based diets with $\mathrm{Cu}, \mathrm{Zn}$, and $\mathrm{Mn}$ from sulfate or hydroxy mineral sources.

${ }^{2}$ Sodium selenate, $200 \mathrm{mg} / \mathrm{kg}$.

${ }^{3}$ Contained $735 \mathrm{kIU}$ of vitamin A/kg, $270 \mathrm{kIU}$ of vitamin D/kg, 4,400 IU of vitamin E/ $\mathrm{kg}$ and $135 \mathrm{mg}$ of biotin (Rovimix Biotin, DSM Nutritional Products, Heerlen, the Netherlands)/kg.

${ }^{4}$ IntelliBond C, Z, M (IntelliBond; Micronutrients USA LLC, Indianapolis, IN). Based on assays, the products contained approximately 59,57 , and $45 \% \mathrm{Cu}, \mathrm{Zn}$, and $\mathrm{Mn}$, respectively.

Table 2. Analyzed nutrient composition of diets and forages without supplemental $\mathrm{Cu}, \mathrm{Zn}$, and $\mathrm{Mn}$

\begin{tabular}{|c|c|c|c|c|c|c|}
\hline Item & \multicolumn{2}{|c|}{$\operatorname{Diet}^{1}$} & $\begin{array}{c}\text { Corn } \\
\text { silage }\end{array}$ & $\begin{array}{l}\text { Alfalfa } \\
\text { silage }\end{array}$ & $\begin{array}{c}\text { Forage } \\
\text { concentrate }\end{array}$ & $\begin{array}{l}\text { By-product } \\
\text { concentrate }\end{array}$ \\
\hline DM, \% & 55.0 & 71.6 & 35.4 & 39.8 & 87.3 & 90.1 \\
\hline $\mathrm{NDF}, \%$ & 25.3 & 36.4 & 32.4 & 36.7 & 10.2 & 37.6 \\
\hline Hemicellulose, $^{2} \%$ & 10.9 & 14.1 & 15.6 & 9.0 & 6.1 & 14.8 \\
\hline$\beta$-Glucan, \% & 0.06 & 0.29 & 0.05 & 0.02 & 0.09 & 0.42 \\
\hline Starch, \% & 35.4 & 17.6 & 39.3 & 1.6 & 49.4 & 14.7 \\
\hline $\mathrm{LCFA},{ }^{4} \%$ & 3.66 & 3.54 & 2.86 & 2.64 & 5.22 & 4.0 \\
\hline $\mathrm{Ca}, \%$ & 0.94 & 1.00 & 0.26 & 1.0 & 1.3 & 0.95 \\
\hline $\mathrm{P}, \%$ & 0.34 & 0.40 & 0.21 & 0.31 & 0.36 & 0.37 \\
\hline $\mathrm{Mg}, \%$ & 0.25 & 0.30 & 0.16 & 0.26 & 0.27 & 0.28 \\
\hline $\mathrm{K}, \%$ & 1.58 & 1.53 & 1.00 & 3.84 & 1.03 & 1.16 \\
\hline S, $\%$ & 0.16 & 0.20 & 0.09 & 0.27 & 0.18 & 0.22 \\
\hline $\mathrm{Mn}, \mathrm{mg} / \mathrm{kg}$ & 38 & 47 & 34 & 65 & 29 & 48 \\
\hline
\end{tabular}

${ }^{1}$ Forage- or by-product-based diets with $\mathrm{Cu}, \mathrm{Zn}$, and $\mathrm{Mn}$ from sulfate or hydroxy mineral sources.

${ }^{2}$ Hemicellulose $=$ NDF - ADF.

${ }^{3}$ Neutral detergent-soluble fiber by difference (Hall et al., 1999).

${ }^{4} \mathrm{LCFA}=$ long-chain fatty acids. 
serum was then harvested $\left(1,000 \times g\right.$ for $10 \mathrm{~min}$ at $\left.4^{\circ} \mathrm{C}\right)$ and frozen $(-20 \mathrm{C})$. Serum, urine, and milk samples were assayed for $\mathrm{Cu}, \mathrm{Zn}$, and $\mathrm{Mn}$ by Michigan State University Veterinary Diagnostic Laboratory (East Lansing, MI) using inductively coupled plasma MS (Wahlen et al., 2005).

\section{Calculations and Statistical Analyses}

Apparent absorption [(intake - fecal)/intake)] and apparent retention (intake - fecal - milk - urine) of $\mathrm{Cu}, \mathrm{Zn}$, and $\mathrm{Mn}$ were calculated for each cow during each of the two 4-d collection periods. Concentrations of all minerals in the water consumed were low (data not shown) and intakes of $\mathrm{Cu}, \mathrm{Zn}$, and $\mathrm{Mn}$ from water were negligible $(<1.0 \mathrm{mg} / \mathrm{d})$ and were not included in retention or absorption measures. All data were analyzed using PROC MIXED of SAS (v9.3; SAS Institute Inc., Cary, NC). One cow fed the by-product treatment with a mineral sequence of sulfate then hydroxy minerals was removed from the experiment after period 1 for reasons not related to treatment. Copper data from 1 group for 1 period was removed because all $\mathrm{Cu}$ apparent retention values were extremely negative (average $=-159 \mathrm{mg} / \mathrm{d}$ ) across all treatments. For unknown reasons, average fecal $\mathrm{Cu}(\mathrm{mg} / \mathrm{kg}$ and $\mathrm{mg} / \mathrm{d})$ were approximately $30 \%$ greater for the removed period compared with the average of all other 5 group-periods. All data other than $\mathrm{Cu}$ were used from this period. Blood indices and digestion data were evaluated using a model that included the fixed effects of fiber $(1 \mathrm{df})$, mineral source $(1 \mathrm{df})$, their interaction $(1 \mathrm{df})$, and the random effects of group (2 df), group $\times$ fiber $(2 \mathrm{df})$, period $(1 \mathrm{df})$, period $\times$ group $(3 \mathrm{df})$, cow within group $\times$ fiber, and residual error.

\section{RESULTS AND DISCUSSION}

Production measures and macronutrient digestibility are discussed elsewhere (Faulkner and Weiss, 2017). Briefly, production measures, with the exception of milk fat and MUN, were not affected by treatment $(P$ $\geq 0.26)$. Cows fed the forage diets had greater milk fat and MUN than cows fed the by-product diets. Digestibility of DM was greater $(P<0.01)$ for forage diets (70.1 vs. $65.5 \%)$, but NDF digestibility was greater $(P$ $<0.01$ ) for by-product diets (50.5 vs. $44.5 \%$ ).

\section{Total-Tract Apparent Mineral Absorption and Balance}

Milk production and DMI (Table 4) during the 4-d collection period were not affected by treatment. Water intake tended $(P=0.10)$ to be greater for cows fed sulfate minerals (Faulkner and Weiss, 2017). Because by-product diets had greater concentrations of basal minerals, intakes of $\mathrm{Cu}, \mathrm{Zn}$, and $\mathrm{Mn}$ were greater $(P<$ 0.01 to 0.07 ) for cows fed by-product diets compared with cows fed forage diets (Table 4). Mineral source did not affect intake of $\mathrm{Cu}$ or $\mathrm{Zn}$ but $\mathrm{Mn}$ intake by cows fed sulfate minerals averaged $4.5 \%$ greater $(P<0.01)$ than for cows fed hydroxy minerals.

Concentrations of $\mathrm{Cu}$ and $\mathrm{Mn}$ in milk were not affected by treatments; however, cows fed hydroxy minerals had lower $(P<0.02)$ concentrations of $\mathrm{Zn}$ in milk $(3.7$ vs $3.9 \mathrm{mg} / \mathrm{kg}$ ) compared with cows fed sulfate minerals (Table 5). This resulted in about a $7 \%$ decrease in the amount of Zn excreted in milk daily $(P<0.01$; Table 4). Milk $\mathrm{Cu}$ and $\mathrm{Mn}$ secretion was $<0.01 \%$ of intake, whereas the amount of $\mathrm{Zn}$ excreted in milk was $\sim 8.0 \%$ of $\mathrm{Zn}$ intake; the reason cows fed sulfates partitioned

Table 3. Concentrations of supplemental and total dietary $\mathrm{Cu}, \mathrm{Zn}$, and $\mathrm{Mn}(\mathrm{mg} / \mathrm{kg}$ of diet DM)

\begin{tabular}{|c|c|c|c|c|}
\hline \multirow[b]{3}{*}{ Item } & \multicolumn{4}{|c|}{ Treatment $^{1}$} \\
\hline & \multicolumn{2}{|c|}{ Forage } & \multicolumn{2}{|c|}{ By-product } \\
\hline & Sulfate & Hydroxy & Sulfate & Hydroxy \\
\hline \multicolumn{5}{|c|}{ Supplemental minerals concentrations ${ }^{2}$} \\
\hline $\mathrm{Cu}$ & 10 & 9 & 11 & 9 \\
\hline $\mathrm{Zn}$ & 34 & 37 & 36 & 34 \\
\hline $\mathrm{Mn}$ & 33 & 32 & 34 & 31 \\
\hline \multicolumn{5}{|c|}{ Total dietary concentrations } \\
\hline $\mathrm{Cu}$ & 19 & 18 & 22 & 20 \\
\hline $\mathrm{Zn}$ & 64 & 67 & 86 & 84 \\
\hline $\mathrm{Mn}$ & 71 & 70 & 81 & 78 \\
\hline \multicolumn{5}{|c|}{ Supplemental mineral, $\%$ of total dietary mineral } \\
\hline $\mathrm{Cu}$ & 53 & 50 & 50 & 45 \\
\hline $\mathrm{Zn}$ & 53 & 55 & 42 & 41 \\
\hline $\mathrm{Mn}$ & 46 & 46 & 42 & 40 \\
\hline
\end{tabular}

${ }^{1}$ Forage- or by-product-based diets with $\mathrm{Cu}, \mathrm{Zn}$, and $\mathrm{Mn}$ from sulfate or hydroxy mineral sources.

${ }^{2}$ Concentrations based on treatment average DMI. 
more $\mathrm{Zn}$ into milk is unknown. Over reasonable ranges in dietary Zn, concentrations of Zn in the diet and milk are not related (Castillo et al., 2013), but excessively high concentrations of dietary $\mathrm{Zn}(540 \mathrm{mg} / \mathrm{kg}$ of diet DM) can increase milk concentrations (Sobhanirad et al., 2010). Source of Zn (sulfate vs. different forms of organic Zn) did not affect Zn concentration in bovine colostrum (Muehlenbein et al., 2001; Formigoni et al., 2011) or milk (Sobhanirad et al., 2010). However, Cope et al. $(2009)$ reported an interaction $(P<0.06)$ between $\mathrm{Zn}$ source (oxide or organic) and dietary concentration of $\mathrm{Zn}$ (approximately 41 and $63 \mathrm{mg} / \mathrm{kg}$ of diet DM). At greater concentrations of dietary $\mathrm{Zn}$, Zn concentrations in milk were greater for cows fed $\mathrm{ZnO}$, but the opposite was true at the lesser dietary concentration.

Urinary loss of trace minerals was $<2 \%$ of intake (Table 4). Loss of urinary $\mathrm{Cu}$ was not affected by treat- ment, but cows fed by-product diets had greater urinary excretion of $\mathrm{Zn}(P<0.01)$ and $\mathrm{Mn}(P<0.03)$ than cows fed the forage-based diets (Table 4$)$. Urinary loss of $\mathrm{Zn}$ and $\mathrm{Mn}$ was less than $2 \mathrm{mg} / \mathrm{d}$, and the average difference between fiber treatments was $0.6 \mathrm{mg} / \mathrm{d}$ or less. Relative to the amount of $\mathrm{Zn}$ and $\mathrm{Mn}$ apparently absorbed, the treatment effects on urinary excretion were minor. When urinary losses of $\mathrm{Zn}$ and $\mathrm{Mn}$ were expressed relative to their intakes, treatment effects were reduced (Table 4). Mean urinary $\mathrm{Cu}$ excretion was greater than reported in other studies (Buckley, 1991; Gustafson, 2000), but $\mathrm{Cu}$ intakes by cows in those studies were 20 to $44 \%$ less than our study, which could explain the differences.

Treatment effects on apparent absorption were not consistent across the minerals examined (Table 4). No treatment effects or interactions were found for $\mathrm{Zn}$, but

Table 4. Effects of fiber and trace mineral sources on mineral apparent absorption and retention

\begin{tabular}{|c|c|c|c|c|c|c|c|c|}
\hline \multirow[b]{3}{*}{ Item } & \multicolumn{4}{|c|}{ Treatment $^{1}$} & \multirow[b]{3}{*}{$\mathrm{SEM}^{2}$} & \multirow{2}{*}{\multicolumn{3}{|c|}{$P<$}} \\
\hline & \multicolumn{2}{|c|}{ Forage } & \multicolumn{2}{|c|}{ By-product } & & & & \\
\hline & Sulfate & Hydroxy & Sulfate & Hydroxy & & Fiber $(\mathrm{F})$ & Mineral (M) & $\mathrm{F} \times \mathrm{M}$ \\
\hline \multicolumn{9}{|l|}{ Intake } \\
\hline DM, kg/d & 24.6 & 24.2 & 24.0 & 23.8 & 1.3 & 0.74 & 0.65 & 0.85 \\
\hline $\mathrm{Cu}, \mathrm{mg} / \mathrm{d}$ & 410 & 390 & 450 & 420 & 18 & 0.07 & 0.14 & 0.78 \\
\hline $\mathrm{Zn}, \mathrm{mg} / \mathrm{d}$ & 1,440 & 1,460 & 1,900 & 1,820 & 63 & 0.01 & 0.38 & 0.15 \\
\hline $\mathrm{Mn}, \mathrm{mg} / \mathrm{d}$ & 1,610 & 1,570 & 1,840 & 1,740 & 60 & 0.01 & 0.04 & 0.34 \\
\hline Milk, kg/d & 35.5 & 35.1 & 34.7 & 33.4 & 3.2 & 0.41 & 0.29 & 0.62 \\
\hline $\mathrm{Cu}, \mathrm{mg} / \mathrm{d}$ & 1.5 & 1.4 & 1.3 & 1.2 & 0.2 & 0.52 & 0.11 & 0.65 \\
\hline $\mathrm{Zn}, \mathrm{mg} / \mathrm{d}$ & 147 & 137 & 127 & 120 & 12 & 0.23 & 0.01 & 0.68 \\
\hline $\mathrm{Mn}, \mathrm{mg} / \mathrm{d}$ & 0.9 & 0.9 & 0.9 & 1.0 & 0.1 & 0.88 & 0.91 & 0.68 \\
\hline $\mathrm{Cu}, \%$ of intake & 0.37 & 0.35 & 0.29 & 0.30 & 0.053 & 0.34 & 0.77 & 0.32 \\
\hline $\mathrm{Zn}, \%$ of intake & 10.2 & 9.36 & 6.70 & 6.71 & 0.711 & 0.005 & 0.07 & 0.08 \\
\hline Mn, \% of intake & 0.059 & 0.058 & 0.05 & 0.055 & 0.0058 & 0.36 & 0.59 & 0.38 \\
\hline Urine, $\mathrm{kg} / \mathrm{d}$ & 21.8 & 23.1 & 19.6 & 18.1 & 1.6 & 0.03 & 0.90 & 0.12 \\
\hline $\mathrm{Cu}, \mathrm{mg} / \mathrm{d}$ & 6.3 & 5.1 & 6.5 & 5.5 & 0.8 & 0.67 & 0.14 & 0.92 \\
\hline $\mathrm{Zn}, \mathrm{mg} / \mathrm{d}$ & 1.0 & 1.2 & 1.9 & 1.5 & 0.2 & 0.01 & 0.37 & 0.10 \\
\hline $\mathrm{Mn}, \mathrm{mg} / \mathrm{d}$ & 0.3 & 0.4 & 0.9 & 0.7 & 0.2 & 0.03 & 0.77 & 0.22 \\
\hline $\mathrm{Cu}, \%$ of intake & 1.6 & 1.3 & 1.4 & 1.4 & 0.23 & 0.91 & 0.39 & 0.58 \\
\hline $\mathrm{Zn}, \%$ of intake & 0.07 & 0.08 & 0.10 & 0.08 & 0.01 & 0.19 & 0.74 & 0.24 \\
\hline Mn, \% of intake & 0.02 & 0.03 & 0.05 & 0.04 & 0.01 & 0.07 & 0.95 & 0.30 \\
\hline Feces, $\mathrm{kg} / \mathrm{d}$ of DM & 7.5 & 7.1 & 8.2 & 8.1 & 0.6 & 0.14 & 0.44 & 0.52 \\
\hline $\mathrm{Cu}, \mathrm{mg} / \mathrm{d}$ & 406 & 372 & 409 & 424 & 27 & 0.21 & 0.62 & 0.26 \\
\hline $\mathrm{Zn}, \mathrm{mg} / \mathrm{d}$ & 1,072 & 1,124 & 1,383 & 1,357 & 62 & 0.01 & 0.68 & 0.25 \\
\hline $\mathrm{Mn}, \mathrm{mg} / \mathrm{d}$ & 1,445 & 1,395 & 1,522 & 1,487 & 82 & 0.19 & 0.33 & 0.87 \\
\hline $\mathrm{Cu}, \%$ of intake & 98.4 & 94.9 & 91.4 & 100.1 & 3.93 & 0.74 & 0.34 & 0.05 \\
\hline $\mathrm{Zn}, \%$ of intake & 76.7 & 74.4 & 74.3 & 72.6 & 1.90 & 0.28 & 0.14 & 0.80 \\
\hline Mn, \% of intake & 89.5 & 89.0 & 83.1 & 85.3 & 3.37 & 0.02 & 0.67 & 0.53 \\
\hline \multicolumn{9}{|c|}{ Apparent absorption, $\%$} \\
\hline $\mathrm{Cu}$ & 1.6 & 5.1 & 8.6 & -0.1 & 3.9 & 0.73 & 0.34 & 0.05 \\
\hline $\mathrm{Zn}$ & 25.4 & 23.3 & 27.4 & 25.7 & 1.9 & 0.25 & 0.15 & 0.80 \\
\hline $\mathrm{Mn}$ & 10.5 & 11.0 & 16.9 & 14.7 & 3.4 & 0.02 & 0.67 & 0.53 \\
\hline \multicolumn{9}{|c|}{ Apparent retention, $\mathrm{mg} / \mathrm{d}$} \\
\hline $\mathrm{Cu}$ & -3 & 11 & 29 & -5 & 16 & 0.49 & 0.38 & 0.05 \\
\hline $\mathrm{Zn}$ & 219 & 199 & 389 & 346 & 35 & 0.01 & 0.20 & 0.66 \\
\hline $\mathrm{Mn}$ & 167 & 167 & 315 & 255 & 55 & 0.01 & 0.43 & 0.45 \\
\hline
\end{tabular}

${ }^{1}$ Forage- or by-product-based diets with $\mathrm{Cu}, \mathrm{Zn}$, and $\mathrm{Mn}$ from sulfate or hydroxy mineral sources.

${ }^{2}$ Data were unbalanced due to one missing observation; therefore, the greatest SEM values were reported. 
Table 5. Effects of fiber type and trace mineral source on concentration of minerals excreted

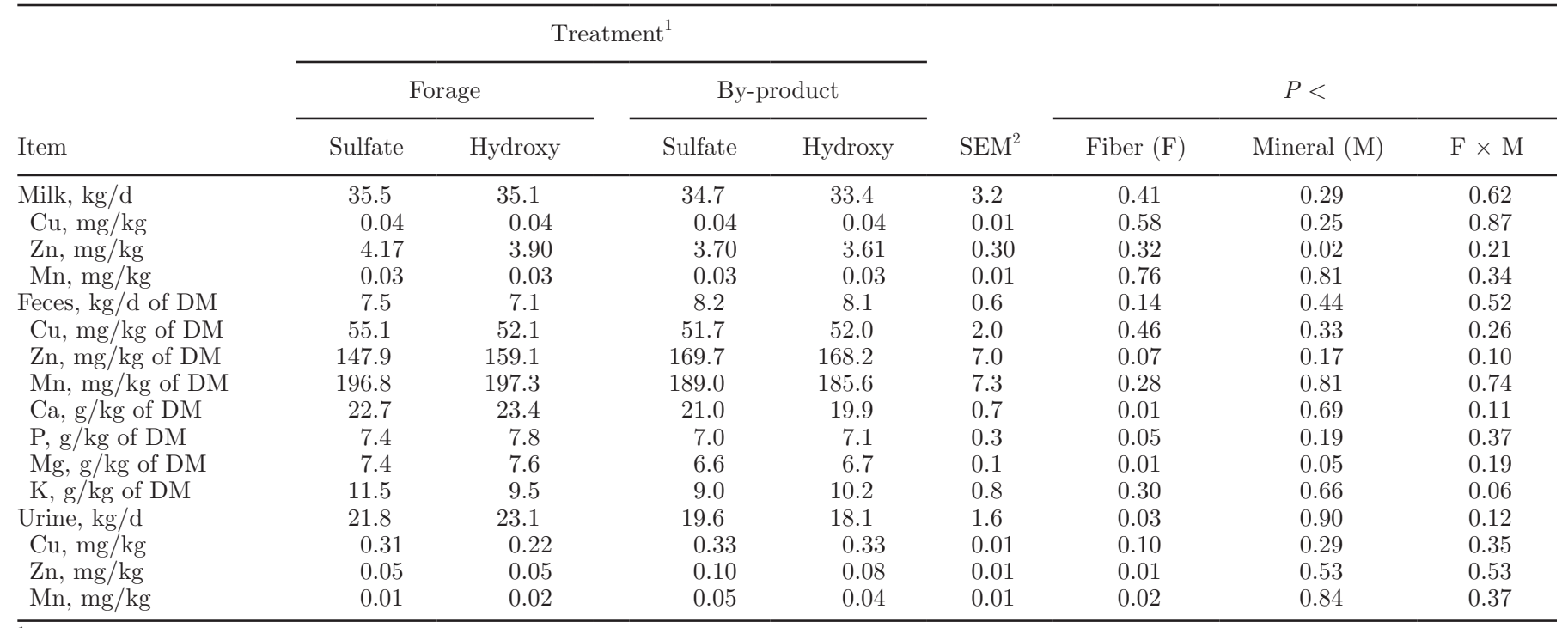

${ }^{1}$ Forage- or by-product-based diets with $\mathrm{Cu}, \mathrm{Zn}$, and $\mathrm{Mn}$ from sulfate or hydroxy mineral sources.

${ }^{2}$ Data were unbalanced due to one missing observation; therefore, the greatest SEM values were reported.

fiber source affected $(P<0.05)$ apparent absorption of $\mathrm{Mn}$ and an interaction $(P<0.05)$ between fiber and mineral source was found for $\mathrm{Cu}$. One potential reason for the differences between the minerals is that they may have different binding affinities for fiber (Ghodrat et al., 2017). Using an in vitro assay, $\mathrm{Cu}$ usually had greater binding affinity than $\mathrm{Zn}$, but Ghodrat et al. (2017) did not include Mn.

A fiber by mineral source interaction $(P<0.05)$ was observed for $\mathrm{Cu}$ apparent absorption and apparent retention (Table 4). For cows fed the forage diets, apparent $\mathrm{Cu}$ retention was greater when hydroxy minerals were supplemented compared with sulfate minerals, but the opposite response was observed for cows fed by-product diets. Greater $\mathrm{Cu}$ apparent absorption for cows fed the forage diet with hydroxy minerals compared with the forage diet with sulfate minerals may be caused by less ruminal antagonism with the less rumen-soluble hydroxy $\mathrm{Cu}$ (Genther and Hansen, 2015). The by-product diets had greater NDF digestibility (50 vs. 44\%) but, because those diets were greater in NDF concentration, output of undigestible NDF was also greater (4.4 vs. 3.4 $\mathrm{kg} / \mathrm{d}$; Faulkner and Weiss, 2017). When apparent $\mathrm{Cu}$ absorption $(\mathrm{mg} / \mathrm{d})$ was regressed on undigested NDF intake, the slope for the by-product diets was not different from zero $(P>0.60)$, whereas the slope of the forage diets $(-8.3 / \mathrm{kg}$ of undigested NDF) was different from zero $(P<0.02)$. These data could mean that undigested fiber from forages had an antagonistic effect of $\mathrm{Cu}$ absorption, whereas the undigested fiber from byproducts does not. However, caution should be taken when interpreting those regressions, as they are based on a limited number of observations and numerous factors other than undigested NDF differed between the forage and by-product diets.

Dry matter from the by-product diets was less digestible than the forage diets (70 vs. 66\%; Faulkner and Weiss, 2017). Poorer solubility of hydroxy $\mathrm{Cu}$ and increased passage of undigested DM could explain the apparent absorption data for the by-product diet. Copper absorption primarily occurs in the small intestine (Wang et al., 2011) via high-affinity copper transporters (Wapnir, 1998; Kim et al., 2008; Han et al., 2009) following the reduction of soluble $\mathrm{Cu}$ by metalloreductase enzymes (Ohgami et al., 2006). Decreased DM digestibility for the by-product diet (Faulkner and Weiss, 2017) would increase the passage of undigested DM through the intestine, reducing the amount of time $\mathrm{Cu}$ spends in the intestine. The hydroxy $\mathrm{Cu}$ may not have had adequate time to solubilize and be reduced, which are necessary steps for absorption by $\mathrm{Cu}$ transporters at intestinal absorption sites. The by-product diet also contained higher concentrations of Fe (Table 2), which can antagonize $\mathrm{Cu}$ (Chase et al., 2000). However, the difference in $\mathrm{Fe}$ concentrations between diets was less than what has been shown to affect $\mathrm{Cu}$ status, and the $\mathrm{Fe}$ in the diets in our study likely were less reactive than the Fe sulfate used by Chase et al. (2000).

Treatment did not affect apparent Zn absorption (Table 4), but cows fed by-product diets had greater $(P$ $<0.01)$ apparent retention of $\mathrm{Zn}$. The greater retention was probably caused in part by greater intake, but, 
Table 6. Effects of fiber type and trace mineral source on selected macromineral apparent absorption

\begin{tabular}{|c|c|c|c|c|c|c|c|c|}
\hline \multirow[b]{3}{*}{ Item } & \multicolumn{4}{|c|}{ Treatment $^{1}$} & \multirow[b]{3}{*}{$\mathrm{SEM}^{2}$} & \multirow{2}{*}{\multicolumn{3}{|c|}{$P<$}} \\
\hline & \multicolumn{2}{|c|}{ Forage } & \multicolumn{2}{|c|}{ By-product } & & & & \\
\hline & Sulfate & Hydroxy & Sulfate & Hydroxy & & Fiber $(\mathrm{F})$ & Mineral (M) & $\mathrm{F} \times \mathrm{M}$ \\
\hline \multicolumn{9}{|c|}{ Intake, $\mathrm{g} / \mathrm{d}$} \\
\hline $\mathrm{P}$ & 84 & 82 & 95 & 94 & 5 & 0.06 & 0.64 & 0.92 \\
\hline $\mathrm{Mg}$ & 62 & 61 & 70 & 69 & 4 & 0.07 & 0.58 & 0.98 \\
\hline \multicolumn{9}{|c|}{ Fecal excretion, g/d } \\
\hline $\mathrm{P}$ & 55 & 56 & 58 & 59 & 4 & 0.69 & 0.67 & 0.77 \\
\hline $\mathrm{Mg}$ & 54 & 55 & 54 & 54 & 4 & 0.93 & 0.92 & 0.79 \\
\hline K & 85 & 69 & 73 & 85 & 9 & 0.80 & 0.74 & 0.05 \\
\hline \multicolumn{9}{|c|}{ Apparent absorption, \% } \\
\hline $\mathrm{P}$ & 34.2 & 32.4 & 39.5 & 38.9 & 2.4 & 0.04 & 0.41 & 0.67 \\
\hline $\mathrm{Mg}$ & 12.3 & 11.2 & 22.9 & 21.6 & 2.0 & 0.01 & 0.25 & 0.94 \\
\hline K & 77.7 & 81.8 & 80.4 & 77.3 & 2.0 & 0.66 & 0.76 & 0.05 \\
\hline
\end{tabular}

${ }^{1}$ Forage- or by-product-based diets with $\mathrm{Cu}, \mathrm{Zn}$, and Mn from sulfate or hydroxy mineral sources.

${ }^{2}$ Data were unbalanced due to one missing observation; therefore, the greatest SEM values were reported.

when expressed as a percent of $\mathrm{Zn}$ intake, $\mathrm{Zn}$ retention by cows fed by-product diets was still greater $(P<$ 0.01; data not shown).

Apparent $\mathrm{Mn}$ absorption $(P=0.02)$ and retention $(P<0.01)$ were greater for cows consuming the byproduct diets compared with the forage diets, but were not affected by mineral source or the fiber by mineral interaction $(P<0.54)$. Apparent $\mathrm{Mn}$ absorption for the forage diets (approximately 11\%) was greater than that measured in late-gestation dairy cows (Weiss and Socha, 2005). A possible reason for the difference is that cows in our study were consuming about $44 \%$ more $\mathrm{Mn}$ and Weiss and Socha (2005) fed Mn methionine and Mn sulfate rather than hydroxy Mn.

\section{Macromineral Absorption}

Trace mineral source did not affect apparent absorption of selected macrominerals, but cows fed the byproduct diets had greater $(P<0.05)$ apparent absorption of $\mathrm{P}$ and $\mathrm{Mg}$ (Table 6 ). An interaction between fiber and trace mineral source was observed $(P<0.05)$ for apparent absorption of K. The major factors affecting $\mathrm{Mg}$ apparent absorption were concentration of dietary K and source of Mg (Weiss, 2004; Schonewille et al., 2008). The concentration of $\mathrm{K}$ was similar between diets, but ingredients and concentration of $\mathrm{MgO}$ differed greatly between the forage and by-product diets. Magnesium oxide provided twice as much $\mathrm{Mg}$ in the forage diets than in the by-product diets (Table 1), and, contrary to NRC (2001), Mg in basal feeds is more available than $\mathrm{Mg}$ from $\mathrm{MgO}$ (Davenport et al., 1990; Jittakhot et al., 2004). Several factors can increase apparent absorption of $\mathrm{P}$ including decreased $\mathrm{P}$ intake and concentration of dietary NDF (Klop et al.,
2013) and increased digestibility of diet DM (Weiss and Wyatt, 2004). The availability of $\mathrm{P}$ also differs among ingredients (Feng et al., 2016). The greater apparent absorption of $\mathrm{P}$ for the by-product diets contradicts many of these relationships. The by-product diet had lower DM digestibility (Faulkner and Weiss, 2017), had greater NDF concentrations (Table 2), and cows fed those diets tended to have greater $(P<0.06) \mathrm{P}$ intake. The ingredients in the by-product diets could have had greater $\mathrm{P}$ availability than those in the forage diets, or equations generated mostly from forage-based diets (e.g., Weiss and Wyatt, 2004; Klop et al., 2013) do not fit when cows are fed low-forage, higher-by-product diets.

A fiber $\times$ mineral interaction was observed for apparent absorption of K (Table 6). Greater K apparent absorption was observed when cows were fed the forage diets with hydroxy minerals compared with sulfates, but the opposite was observed with the by-product diets. Feed K exists as simple ions readily available for absorption (Emanuele and Staples, 1990; Ledoux and Martz, 1991). The main route of $\mathrm{K}$ excretion is through urine, and is under primary regulation by aldosterone, and can be further affected by blood acid-base balance (McGuirk and Butler, 1980). Urinary K excretion was not measured, however decreased fecal excretion of $\mathrm{K}$ by cows fed the forage diet with hydroxy minerals and by-product diet with sulfate minerals likely led to greater urinary $\mathrm{K}$ excretion (Table 6).

\section{Red Blood Cell SOD Activity and Blood Serum Concentrations}

No treatment differences were observed for serum $\mathrm{Cu}, \mathrm{Zn}, \mathrm{Mn}$, or Fe concentrations (Table 7); however, 
Table 7 . The effects of fiber and mineral source on enzyme activity and serum mineral concentrations

\begin{tabular}{|c|c|c|c|c|c|c|c|c|}
\hline \multirow[b]{3}{*}{ Blood measure } & \multicolumn{4}{|c|}{ Treatment $^{1}$} & \multirow[b]{3}{*}{$\mathrm{SEM}^{2}$} & \multirow{2}{*}{\multicolumn{3}{|c|}{$P<$}} \\
\hline & \multicolumn{2}{|c|}{ Forage } & \multicolumn{2}{|c|}{ By-product } & & & & \\
\hline & Sulfate & Hydroxy & Sulfate & Hydroxy & & Fiber $(\mathrm{F})$ & Mineral (M) & $\mathrm{F} \times \mathrm{M}$ \\
\hline $\mathrm{Cu}, \mathrm{mg} / \mathrm{L}$ & 0.75 & 0.79 & 0.83 & 0.82 & 0.07 & 0.57 & 0.61 & 0.50 \\
\hline $\mathrm{Zn}, \mathrm{mg} / \mathrm{L}$ & 1.08 & 1.16 & 1.10 & 1.14 & 0.08 & 1.00 & 0.10 & 0.47 \\
\hline $\mathrm{Mn}, \mu \mathrm{g} / \mathrm{L}$ & 2.64 & 2.44 & 2.46 & 2.34 & 0.36 & 0.67 & 0.66 & 0.91 \\
\hline Hemoglobin, mg/dL & 103 & 104 & 114 & 112 & 3.31 & 0.01 & 0.57 & 0.16 \\
\hline $\begin{array}{l}\text { Superoxide dismutase } \\
\text { activity/g of hemoglobin }\end{array}$ & 3,234 & 3,150 & 3,049 & 3,237 & 170.5 & 0.76 & 0.54 & 0.12 \\
\hline
\end{tabular}

${ }^{1}$ Forage- or by-product-based diets with $\mathrm{Cu}, \mathrm{Zn}$, and Mn from sulfate or hydroxy mineral sources.

${ }^{2}$ Data were unbalanced due to one missing observation; therefore, the greatest SEM values were reported.

cows consuming hydroxy minerals tended to have greater serum $\mathrm{Zn}$ concentrations $(P=0.10)$. Concentrations of $\mathrm{Cu}, \mathrm{Zn}$, and $\mathrm{Mn}$ in serum are usually poor measures of adequacy and are not sensitive to changes in dietary supply (Sol Morales et al., 2000; Mullis et al., 2003; Hansen et al., 2006). With the exception of a trend toward higher $\mathrm{Zn}$ concentrations $(P<0.10)$ when hydroxy minerals were fed, serum minerals were not affected by treatment (Table 7).

Fiber, mineral, and interaction effects were observed for serum Mo (Table 7). Concentrations of serum Mo were greater for cows consuming the forage diets compared with by-product diets $(P<0.01)$ and sulfate minerals compared with hydroxy $(P=0.03)$. Dietary concentration of Mo was slightly greater for the forage diets than the by-product diets (1.81 vs $1.60 \mathrm{mg} / \mathrm{kg}$ ); however, it is unlikely that a $12 \%$ increase in dietary Mo from the forage diets increased serum Mo concentrations $>400 \%$. The reason for the difference in serum Mo is not known, but it could be caused by differences in Mo availability between dietary ingredients. Decreased rumen soluble hydroxy $\mathrm{Cu}$ compared with sulfate sources may have lessened $\mathrm{Cu}$ and thiomolybdate binding in the rumen, thereby increasing thiomolybdate (i.e., Mo) absorption. Hemoglobin concentrations were within the normal range but for unknown reasons were higher $(P$

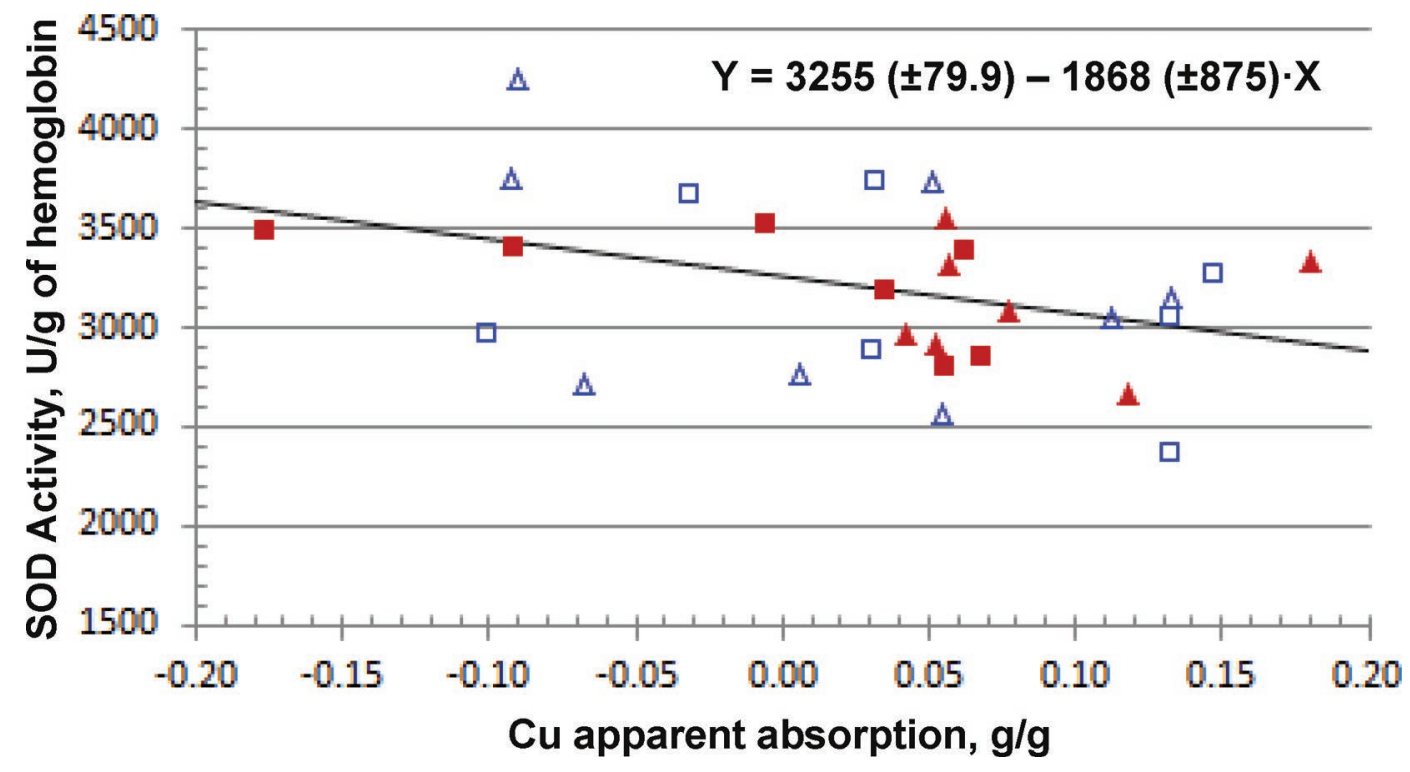

Figure 1. Relationship between apparent absorption of $\mathrm{Cu}$ and superoxide dismutase (SOD) activity in red blood cells in lactating dairy cows fed forage (blue, open symbols) or by-product (red, closed symbols) based diets with sulfate (triangles) or hydroxy (squares) supplemental $\mathrm{Cu}, \mathrm{Zn}$, and $\mathrm{Mn}$. Treatment did not affect slope or intercept and the common slope and intercept are different from zero $(P<0.05$; root mean squared error $=400.8$ ). Color version available online. 
$=0.01)$ for cows fed the forage diets compared with the by-product diets. Superoxide dismutase activity in erythrocytes (i.e., SOD1) was not affected by fiber or mineral main effects but tended $(P=0.12)$ toward an interaction between fiber treatment and mineral source; with the forage diets, cows fed sulfate minerals had higher activity of SOD than those fed hydroxy minerals, but the opposite was found when by-product diets were fed (Table 7). This interaction is opposite of the interaction observed for apparent $\mathrm{Cu}$ absorption (Table 4). Activity of SOD was negatively associated $(P<0.05)$ with apparent $\mathrm{Cu}$ absorption (Figure 1). A weaker $(P<0.07)$ negative relationship was observed between SOD and apparent Zn absorption (data not shown). One explanation for this apparent paradoxical relationship between SOD and apparent absorption of $\mathrm{Cu}$ is that cows with higher SOD activity may reflect a state of excess $\mathrm{Cu}$, and excess body $\mathrm{Cu}$ may lead to downregulation of $\mathrm{Cu}$ absorption (van den Berghe and Klomp, 2009).

\section{CONCLUSIONS}

Absorption and retention of Zn were not affected by diet or source of metal. The by-product-based diets had greater apparent Mn absorption than forage-based diets, which could reflect differences in absorption of Mn from the feedstuffs or could be caused by differences in $\mathrm{Mn}$ intake. Fiber source affected $\mathrm{Cu}$ absorption, but the effects were different depending on the source of supplemental trace minerals. Absorption of $\mathrm{Cu}$ from $\mathrm{Cu}$ sulfate, but not from hydroxy $\mathrm{Cu}$, was negatively influenced by the forage-based diet, possibly because of differences in mineral interaction with digesta in the rumen. However, when a by-product-based diet was fed, absorption of $\mathrm{Cu}$ from hydroxy $\mathrm{Cu}$ was lesser than that from $\mathrm{Cu}$ sulfate possibly because of decreased solubility of hydroxy $\mathrm{Cu}$ at the interface between digesta and the enterocytes. Because DM digestibility of the byproduct diets was less than that of the forage diets, the increased mass of digesta flowing through the intestine could potentially reduce access of $\mathrm{Cu}$ to the enterocyte. A paradoxical relationship of higher SOD activity with lesser apparent absorption of $\mathrm{Cu}$ may reflect regulation of $\mathrm{Cu}$ absorption and warrants further investigation.

\section{ACKNOWLEDGMENTS}

This study was partially funded by Micronutirents USA LLC (Indianapolis, IN). Thanks are extended to MaryBeth Hall and Jan Pitas for conducting the soluble fiber assays.

\section{REFERENCES}

AOAC International. 2000. Official Methods of Analysis. Vol. 1 and 2. 17th ed. AOAC International, Gaithersburg, MD.

Buckley, W. T. 1991. A kinetic model of copper metabolism in lactating dairy cows. Can. J. Anim. Sci. 71:155-166.

Cao, J., P. R. Henry, C. B. Ammerman, R. D. Miles, and R. C. Littell. 2000. Relative bioavailability of basic zinc sulfate and basic zinc chloride for chicks. J. Appl. Poult. Res. 9:513-517.

Castillo, A. R., N. R. St-Pierre, N. Silva del Rio, and W. P. Weiss. 2013. Mineral concentrations in diets, water, and milk and their value in estimating on-farm excretion of manure minerals in lactating dairy cows. J. Dairy Sci. 96:3388-3398.

Chase, C. R., D. K. Beede, H. H. Van Horn, J. K. Shearer, C. J. Wilcox, and G. A. Donovan. 2000. Responses of lactating dairy cows to copper source, supplementation rate, and dietary antagonist (iron). J. Dairy Sci. 83:1845-1852.

Clark, P. W., and L. E. Armentano. 1993. Effectiveness of neutral detergent fiber in whole cottonseed and dried distillers grains compared with alfalfa haylage. J. Dairy Sci. 76:2644-2650.

Cope, C. M., A. M. Mackenzie, D. Wilde, and L. A. Sinclair. 2009. Effects of level and form of dietary zinc on dairy cow performance and health. J. Dairy Sci. 92:2128-2135.

CVAS (Cumberland Valley Analytical Services). 2014. Resource-lab procedures. Accessed Sep. 10, 2015. http://www.Foragelab.com/ Resources/Lab-Procedures.

Davenport, G. M., J. A. Boling, and N. Gay. 1990. Bioavailability of magnesium in beef cattle fed magnesium oxide or magnesium hydroxide. J. Anim. Sci. 68:3765-3772.

Drews, L. M., C. Kies, and H. M. Fox. 1979. Effect of dietary fiber on copper, zinc, and magnesium utilization by adolescent boys. Am. J. Clin. Nutr. 32:1893-1897.

Emanuele, S. M., and C. R. Staples. 1990. Ruminal release of minerals from six forage species. J. Anim. Sci. 68:2052-2060.

Faulkner, M. J., and W. P. Weiss. 2017. Effect of source of trace minerals in either forage- or by-product-based diets fed to dairy cows: 1. Production and macronutrient digestibility. J. Dairy Sci. 100:5358-5367. https://doi.org/10.3168/jds.2016-12095.

Feng, X., J. P. Jarrett, K. F. Knowlton, R. E. James, and M. D. Hanigan. 2016. Short communication: Comparison of predicted ration phosphorus balance using bioavailabilities from the NRC (2001) and Virginia Tech models. J. Dairy Sci. 99:1237-1241.

Formigoni, A., M. Fustini, L. Archetti, S. Emanuele, C. Sniffen, and G. Biagi. 2011. Effects of an organic source of copper, manganese and zinc on dairy cattle productive performance, health status and fertility. Anim. Feed Sci. Technol. 164:191-198.

Genther, O. N., and S. L. Hansen. 2015. The effect of trace mineral source and concentration on ruminal digestion and mineral solubility. J. Dairy Sci. 98:566-573.

Ghodrat, A., A. Yaghobfar, Y. Ebrahimnezhad, H. Aghdam Shahryar, and A. Ghorbani. 2017. In vitro binding capacity of organic (wheat bran and rice bran) and inorganic (perlite) sources for $\mathrm{Mn}, \mathrm{Zn}, \mathrm{Cu}$, and Fe. J. Appl. Anim. Res. 45:80-84.

Grant, R. J. 1997. Interactions among forages and nonforage fiber sources. J. Dairy Sci. 80:1438-1446.

Gustafson, G. M. 2000. Partitioning of nutrient and trace elements in feed among milk, faeces and urine by lactating dairy cows. Acta Agric. Scand. A Anim. Sci. 50:111-120.

Hall, M. B., W. H. Hoover, J. P. Jennings, and T. K. M. Webster. 1999. A method for partitioning neutral detergent-soluble carbohydrates. J. Sci. Food Agric. 79:2079-2086.

Han, H., S. L. Archibeque, and T. E. Engle. 2009. Characterization and identification of hepatic mRNA related to copper metabolism and homeostasis in cattle. Biol. Trace Elem. Res. 129:130-136.

Hansen, S. L., J. W. Spears, K. E. Lloyd, and C. S. Whisnant. 2006. Feeding a low manganese diet to heifers during gestation impairs fetal growth and development. J. Dairy Sci. 89:4305-4311.

Jittakhot, S., J. T. Schonewille, H. Wouterse, C. Yuangklang, and A. C. Beynen. 2004. Apparent magnesium absorption in dry cows fed 
at 3 levels of potassium and 2 levels of magnesium intake. J. Dairy Sci. 87:379-385.

Kim, B.-E., T. Nevitt, and D. J. Thiele. 2008. Mechanisms for copper acquisition, distribution and regulation. Nat. Chem. Biol. 4:176185.

Klop, G., J. L. Ellis, A. Bannink, E. Kebreab, J. France, and J. Dijkstra. 2013. Meta-analysis of factors that affect the utilization efficiency of phosphorus in lactating dairy cows. J. Dairy Sci. 96:3936-3949.

Ledoux, D. R., and F. A. Martz. 1991. Ruminal solubilization of selected macrominerals from forages and diets. J. Dairy Sci. 74:1654-1661.

McGuirk, S. M., and D. G. Butler. 1980. Metabolic alkalosis with paradoxic aciduria in cattle. J. Am. Vet. Med. Assoc. 177:551-554.

Muehlenbein, E. L., D. R. Brink, G. H. Deutscher, M. P. Carlson, and A. B. Johnson. 2001. Effects of inorganic and organic copper supplemented to first-calf cows on cow reproduction and calf health and performance. J. Anim. Sci. 79:1650-1659.

Mullis, L. A., J. W. Spears, and R. L. McCraw. 2003. Effects of breed (Angus vs Simmental) and copper and zinc source on mineral status of steers fed high dietary iron. J. Anim. Sci. 81:318-322.

NRC. 2001. Nutrient Requirements of Dairy Cattle. 7th rev. ed. ed. Natl. Acad. Sci., Washington, DC.

Ohgami, R. S., D. R. Campagna, A. McDonald, and M. D. Fleming. 2006. The Steap proteins are metalloreductases. Blood 108:13881394.

Schonewille, J. T., H. Everts, S. Jittakhot, and A. C. Beynen. 2008. Quantitative prediction of magnesium absorption in dairy cows. J. Dairy Sci. 91:271-278.

Sobhanirad, S., D. Carlson, and R. Bahari Kashani. 2010. Effect of zinc methionine or zinc sulfate supplementation on milk production and composition of milk in lactating dairy cows. Biol. Trace Elem. Res. 136:48-54.
Sol Morales, M., D. L. Palmquist, and W. P. Weiss. 2000. Milk fat composition of Holstein and Jersey cows with control or depleted copper status and fed whole soybeans or tallow. J. Dairy Sci. 83:2112-2119.

Torre, M., A. R. Rodriguez, and F. Saura-Calixto. 1991. Effects of dietary fiber and phytic acid on mineral availability. Crit. Rev. Food Sci. Nutr. 30:1-22.

van den Berghe, P. V., and L. W. Klomp. 2009. New developments in the regulation of intestinal copper absorption. Nutr. Rev. 67:658 672

van der Aar, P. J., G. C. Fahey Jr., S. C. Ricke, S. E. Allen, and L. L. Berger. 1983. Effects of dietary fibers on mineral status of chicks. J. Nutr. 113:653-661.

Wahlen, R., L. Evans, J. Turner, and R. Hearn. 2005. The use of collision/reaction cell ICP-MS for the determination of elements in blood and serum samples. Spectroscopy (Springf.) 20:1-6.

Wang, Y., V. Hodgkinson, S. Zhu, G. A. Weisman, and M. J. Petris. 2011. Advances in the understanding of mammalian copper transporters. Adv. Nutr. 2:129-137.

Wapnir, R. A. 1998. Copper absorption and bioavailability. Am. J. Clin. Nutr. 67:1054S-1060S.

Weiss, W. P. 2004. Macromineral digestion by lactating dairy cows: Factors affecting digestibility of magnesium. J. Dairy Sci. 87:21672171.

Weiss, W. P., and M. T. Socha. 2005. Dietary manganese for dry and lactating Holstein cows. J. Dairy Sci. 88:2517-2523.

Weiss, W. P., N. R. St-Pierre, and L. B. Willett. 2009. Varying type of forage, concentration of metabolizable protein, and source of carbohydrate affects nutrient digestibility and production by dairy cows. J. Dairy Sci. 92:5595-5606.

Weiss, W. P., and D. J. Wyatt. 2004. Macromineral digestion by lactating dairy cows: Estimating phosphorus excretion via manure. J. Dairy Sci. 87:2158-2166. 